\title{
Motivation factors for visiting religious sites: The case of Lesvos Island
}

\author{
Irene Kamenidou ${ }^{1 *}$ and Rafaela Vourou ${ }^{2}$
}

Received: 21/11/2013 Accepted: 24/04/2014

\begin{abstract}
1 Marketing Professor. School of Management and Economics, Department of Business Administration, Eastern Macedonian and Thrace Institute of Technology, Ag. Loukas Kavala, 654 04, Greece. E-mail: rkam@teikav.edu.gr, phone: +030 2510462157

2 School of Management and Economics, Department of Business Administration, Eastern Macedonian and Thrace Institute of Technology. E-mail: Rafaelavourou13@gmail.com

* Corresponding author
\end{abstract}

\section{Abstract}

This study investigates tourist's motivations for visiting religious sites in Lesvos, a religious destination island in Greece. Data was collected in Lesvos during the Orthodox Easter period of 2013 implementing a sample of 210 tourists who had visited a monastery during their stay on the island. In order to measure tourists' motivation for religious site visitation in Lesvos, 15 motivation components were used. Data analysis included descriptive analysis and factor analysis. The findings based on descriptive statistics (Mean Scores) suggest that the main reasons for visitation to monasteries and churches in Lesvos Island were pilgrimage motives, i.e. "To worship", "I have made a vow" and "In order to get well (health reasons)". On the other hand, the reasons with the lowest Mean Scores regarding visitation to monasteries and churches in Lesvos Island were secular reasons: "It is in "fashion"- it is trendy", "To do shopping", and for "Research /educational reasons". Factor analysis of the motivations components identified 3 factors, interpreting $66.5 \%$ of the total variance, i.e. "Secular and cultural motives", "Pilgrimage motives", and "Spiritual motives". The findings of this research offer important practical implications for promoting Lesvos for religion tourism.

(C) 2015 International University College. All rights reserved

Keywords: religion tourism; tourist motivation; pilgrimage, tourist behaviour

Citation: Kamenidou, I. and Vourou, R. (2015) Motivation factors for visiting religious sites: The case of Lesvos Island. European Journal of Tourism Research 9, pp. 78-91

\section{Introduction}

Religious tourism regards to visitors who "are partially or exclusively motivated for religious reasons" (Rinschede, 1992:52). This is presented with the pilgrim-tourist path continuum developed by Smith (1992).

The World Tourism Organization (UNWTO, 2011) estimates that 300 to 330 million people 
travel annually on religious sites while the Alliance of Religions and Conservation (ARC, 2011) estimates that a total of 140 million pilgrimages travel per year only to 32 destinations alone. Tarlow (2011), states that religious travel is estimated at a value of USD 18 billion dollars and 300 million travellers yearly being one of the fastest growing segments in travel and tourism. Having this in mind, the Greek National Tourist Organization (GNTO) has produced downloadable leaflets with an indicative list of 100 religious monuments (Real Society, 2012) in order to increase religious tourism.

Religious tourism aroused the interest of many researchers and practitioners (Drule et al., 2012). Timothy and Olsen (2006 in Nieminen, 2009), state that religious tourism is one of the least studied areas in tourism research and Poria et al., (2003) state that even less studied is travel motivations of religious tourists. Today, 10 years after, even though the number of studies regarding religious or faith tourism has increased significantly, they are still relatively less than other aspects of tourism (search in scholar.google.com and google.com).

Several studies have been found regarding tourists' motivation for visiting a sacred site (e.g. Drule et al., 2012; Egresi et al., 2012; Rodrigues, 2012; Hyde and Harman, 2011; Chand, 2010; Tîrca et al., 2010; Triantafillidou et al., 2010; Vidic, 2007; Sharpley and Sundaram, 2005; Collins-Kreiner and Kliot, 2000). One would expect that research on religious tourism regarding Greece would be abundant since there are numerous religious sites for visitation, and since it is world-wide known for its monasteries, chapels, etc.

On the contrary, there are very few empirical studies regarding Greece and religious tourism in general. Studies found that refer to Greece, and religious tourism are those of della Dora (2012); Kotsi (2012); Petreas (2011); Terzidou (2010); Aslan and Andriotis (2009); and Terzidou et al., (2008). Focusing even more, on tourists' motivation visiting religious sites in Greece, only two studies to the authors knowledge exist (Terzidou, 2010; Aslan and Andriotis, 2009).
Literature states (e.g. Egresi et al., 2012) that it is vital for religious destinations (i.e. Lesvos) to identify their tourists motivations in order the local authorities could make strategic and marketing decisions for long-term growth.

Furthermore, destination managers and policy makers can gain a better knowledge and a clear understanding of the different market segments based on the wants, needs and benefits sought. With this knowledge, they may build appropriate strategies for revisit and attraction of potential visitors (Priporas et al., 2012; Kamenidou et al., 2009).

Under this context, this research which is exploratory in nature, aims to investigate tourists' motivations for visiting sacred sites in Lesvos Island, i.e. the monasteries and churches. Furthermore, it has as its first objective to record previous visitation to Lesvos Island and the purpose of previous visitation. Its second objective is to examine the source of information regarding the island, and visitation to sacred sites and monuments (mainly monasteries and secondly churches). Lastly, the third objective of this study is to extract the underlying factors of tourists' motivations for visiting monasteries and churches in Lesvos.

This research is considered of great importance for Greek and local authorities as well as for the bodies of tourism planning policy, since it is the first attempt to record tourists' specific motivations regarding Lesvos as a religious tourism destination. Furthermore, it adds to the body of the literature on tourists' motivations for visiting religious sites, offering findings from the Greek context.

The structure of the article is as follows. First, a brief review on religious tourism literature is provided, followed by a synopsis of Lesvos as a religion destination. Next, the research methodology is presented. Subsequently, the results of the research as well as the discussion are provided. Lastly, the conclusions, the recommendations and the limitations of the research are presented.

\section{Literature review}

Religious tourism is linked to visitors who "are motivated either in part or exclusively for 
religious reasons" (Rinschede, 1992:52). Smith (1992) presented the pilgrim-tourist path continuum on which on one edge pilgrimage was located, and on the other edge tourism. In the intermediate area was the religious tourism (faith/profane, knowledge based tourism). According to academics, tourists' motivation is what differentiates them from pilgrims or secular tourists (Shuo et al., 2009). On the other hand, Tomasi (2002:20) points out "The distinction between pilgrimage driven by faith and tourism for cultural and recreational purposes no longer holds because contemporary pilgrimages involve such large numbers of people that they can only be organized in the same manner as mass tourism".

Drule et al., (2012) in their study of nonreligious motivations of 1600 Orthodox people from Romania who visited a monastery found that visitors are mainly motivated by a selfactualization need, i.e. their desire to become better persons. Rodrigues (2012) studied motives for visiting Tyburn Monastery, New Zealand with a mixed method research approach. Specifically, she conducted 22 semistructured interviews and collected 42 questionnaires with visitors to the monastery, as well as in-depth interviews with three of the monastic nuns. Three main motivational themes derived: religious, personal and social motives while the quantitative data revealed the main motives for visiting the monastery were to 'spend time with God', 'to nurture your faith', 'and 'to pray'. Three key experiential themes emerged from the qualitative analysis through the respondents' narratives of their experiences at the monastery. These were 'religious element' 'personal experience' and 'social setting element'. Hyde and Harman (2011) in their study identified Australians' and New Zealanders' travellers' motives for a secular pilgrimage to the Gallipoli battlefields in Turkey. Five motives were identified i.e. spiritual, nationalistic, family pilgrimage, friendship and travel motives. Collins-Kreiner and Kliot (2000) found that motives for visiting the Holy Land were among others vows to God, prayer, faith, and spiritual peace. Triantafillidou et al., (2010) in their research found that some of the motives for Greeks travelling to the Holly Land was faith, strong religious reasons, pray, health recovery reasons, reasons connected to their baptism, being closer to God and Jesus Christ. Tîrca et al., (2010) in their study found that motives to travel to religious settlements among other were to pray for various needs; to find God; for silence and peace; to thank for benefaction; for repentance; for guidance; and to consolidate their faith in God. Moreover, as to other motives of people travelling to monasteries, other than religious, are curiosity, relaxation, and cultural motivation. Chand (2010) in his study made a comparison of religious motivations among 500 domestic visitors and 500 non-resident Indians visiting Sacred Sites in India. 26 motivational items were used. Factor analysis produced five factors labelled as: Cultural Immersion, Religious Attraction, Seeking Camaraderie, Novelty, and Family Togetherness. Sharpley and Sundaram (2005) in their study found that motives for visiting a religious site is amongst other: a spiritual experience, historical and cultural or educational reasons. Vidic (2007) in her study found that motives to visit the monasteries within Fruska Gora were among other and in order of importance: religion and spiritual reasons, curing, cultural reasons, and religious events and manifestations. Lastly, Egresi et al. (2012) in their study found that religious sites were visited for their historical and cultural value rather than for their sacred and spiritual value.

Terzidou (2010) through 35 in-depth interviews explored religious tourists' motivations for visiting Tinos. She found that there were tourists who had a vow, those who seek therapy, and relieve them from pain, and those who had more secular requests (request for a job, etc). She also found that religious places are not selected out of their appearance but out of their miracles. Aslan and Andriotis (2009) investigated via a self-administrated questionnaire the motivations of 97 tourists visiting Tinos Island. Subsequently, they segmented tourists based on their motivations for visiting. They found three segments: the "cultural tourists", the "vacationers" and the "religious tourists". 


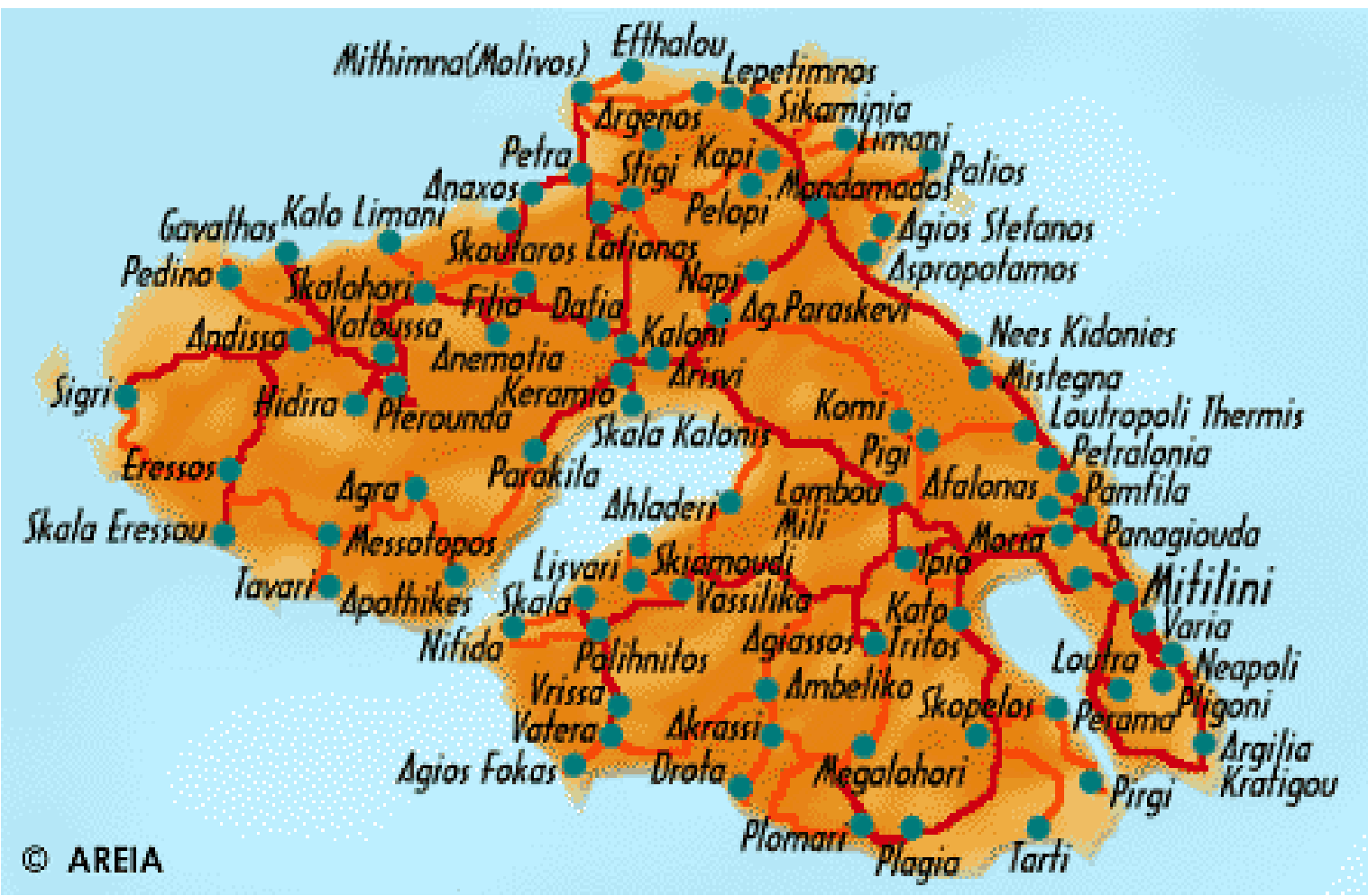

Figure 1: Map of Lesvos Island

http://www.hri.org/infoxenios/english/aegean/lesvos/lesv_map.html

\section{The case study: Lesvos Island as a tourist destination}

Lesvos is one of is of the ten islands (Lesvos, Samos, Chios, Ikaria, Limnos, Fourni, Psara, Inousses, Agios Efstratios and Thimena) which consist the north-eastern Aegean islands (Figure 1). It is popular for its petrified forest which is included in the NATURA 2000 project. Lesvos is also called the island of poets since it is the origin of the popular lyric poets Alkaios and Sapfo, the novelists Argyris Eftaliotis, Stratis Myrivilis, the folk painter Theophilos, as well as Nobel laureate Odysseas Elytis (Ethnos, 2010). Lesvos is a worshiping destination for thousands of orthodox visitors with 15 monasteries, of which, three due to their miracles, are the most visited: Monastery of Saints Raphael, Nicholas and Eirini; Taxiarches Monastery - Mantamados; and Limonos and St. Ignatius Monastery. Also, there are many churches and picturesque chapels. The most recognized are Panagia Glykofylousa or Panagia of Petra, the Church of St Mary the Virgin in Agiasos, and Agios
Athanasios, today's Metropolis Cathedral (Ethnos, 2010; VisitLesvos, n.d.).

\section{Methodology}

This research employed a mixed-methodology approach consisting of qualitative and quantitative tools in order to explore the motivations of visitors at religious sites in Lesvos Island. In December 2012 during the Christmas vacation period qualitative research was utilized through participant observation and depth interviews. This period was chosen because tourism to the island during the big orthodox Christian holidays is increased (Christmas and Easter). Hence, it would be relatively easier to find people to participate in the qualitative research. Participants were recruited with snowball sampling, where friends and relatives indicated other potential participants. Basic condition in order to participate in the qualitative research was to have visited Lesvos Island and a monastery during their stay. Twelve semi structured interviews were conducted. Main questions associated to the aim and objectives stated, 
had to do with sites visited and motivation for visiting religious sites in Lesvos. Through content analysis depth interviews were transcribed and words and phrases were used to develop the quantitative research questionnaire.

The field research questionnaire was developed specifically for this purpose based upon previous research as well as the qualitative research. Studies used for developing the questionnaire, after making where needed the proper modifications were those of Hughes et al., (2013); Drule et al., (2012); Egresi et al., (2012); Rodrigues (2012); Terzidou (2010); Aslan and Andriotis (2009); Shuo et al., (2009); and Vidic (2007). The questionnaire was divided into three parts. The first part included general questions such as previous visit to Lesvos Island, reasons of visit, source of information regarding the island, and if religious points of interest were visited. The second part comprised of questions regarding religious tourism, such as religious sites that were visited (monasteries and churches), motivations and evaluation of visit, satisfaction, recommendation, attitudes, and competitive religious tourism places. The last part of the questionnaire included socioeconomic and demographic questions of participants. In order to measure motivation for visiting religious sites (monasteries and churches) a five point Likert scale was implemented, whereas point $5=$ strongly agree, $4=$ agree, $3=$ neither agree/nor disagree, 2 = disagree, and 1 = strongly disagree.

To define the validity of the questionnaire (Spector, 1992), both face and content validity were adapted. First of all, to assure content validity, the questionnaire was developed based on previous studies regarding motivation to visiting sacred sites as noted earlier. Secondly, in order to test the questionnaire for content validity, it was handed out to faculty from the authors department familiar with this area of studies. Additionally, it was sent to faculty members from other Universities in the country and the United Kingdom, following the procedure of Burr et al., (2007). Moreover, through a pilot test conducted during March of 2013, the questionnaire was tested for face validity following the procedure of Kamenidou (1999:67). Hence, the necessary modifications were made in order to proceed to the field research in Easter time. The questionnaire took its final form in mid April 2013. Quantitative research took place during the Orthodox Easter period of 2013. Two hundred and ten visitors participated in the research, the ones that stated that they had visited a religious site and specifically a monastery, or a church during their stay. A self-completion questionnaire was used, but face to face interviews were employed wherever needed (for older participants). The final sample size consisted of 210 valid questionnaires which can be considered as satisfactory for the purposes of the research as well as the main statistical analysis utilized (Hair et al., 2005). Analysis of data consisted of descriptive statistics, reliability and factor analysis. Descriptive analysis was implemented for the statistical description of individuals' socioeconomic and demographic characteristics, as well as the statistical description and tendencies of tourists' motivation. Reliability analysis was implemented in order to investigate internal consistency of the scale used to measure motivations. Lastly, factor analysis was used in order to capture the underlying dimensions of tourists' motivation for visiting religious sites in Lesvos Islands.

\section{Results and discussion Consumers' profile}

The samples' profile is presented in Table 1. The sample consisted mainly of females (66\%) and with the sample's average age 42 years old with a range from 19-85 years. Regarding marital status $58.1 \%$ married; $35.2 \%$ were employees (private and public), and 33.7\% dependent from other (housewives, students, unemployed). Concerning education, most respondents held at least a bachelor's degree (34.1\%). Lastly, as regards personal monthly net income, the vast majority $(68.8 \%)$ had an income up to $1000.00 €$. 
Table 1. Demographic profile of the sample

\begin{tabular}{|c|c|c|}
\hline Demographic & Frequency & Percentage (\%) \\
\hline \multicolumn{3}{|l|}{ Gender } \\
\hline Male & 71 & 34.0 \\
\hline Female & 139 & 66.0 \\
\hline \multicolumn{3}{|l|}{ Age } \\
\hline $19-25$ & 55 & 26.2 \\
\hline $26-35$ & 39 & 18.6 \\
\hline $36-45$ & 27 & 12.8 \\
\hline $46-55$ & 39 & 18.6 \\
\hline $56-65$ & 31 & 14.8 \\
\hline $65+$ & 19 & 9.0 \\
\hline \multicolumn{3}{|l|}{ Marital Status } \\
\hline Single & 55 & 26.2 \\
\hline Married & 122 & 58.1 \\
\hline Divorced/separated/widowed & 33 & 15.7 \\
\hline \multicolumn{3}{|l|}{ Education } \\
\hline Up to primary education & 38 & 18.5 \\
\hline Secondary and postsecondary education & 72 & 34.1 \\
\hline Bachelor-Master-PhD & 100 & 47.6 \\
\hline \multicolumn{3}{|l|}{ Occupation } \\
\hline Employees (public-private) & 74 & 35.2 \\
\hline Free lancers & 24 & 11.4 \\
\hline Dependent (students, housewives, unemployed) & 71 & 33.7 \\
\hline Workers (skilled-unskilled) & 9 & 4.3 \\
\hline Retired (on pension) & 32 & 15.2 \\
\hline \multicolumn{3}{|l|}{ Personal net monthly income (Euros) } \\
\hline-600.00 & 59 & 28.2 \\
\hline $600.01-1000.00$ & 85 & 40.6 \\
\hline $1000.01-1500.00$ & 41 & 19.3 \\
\hline $1500.01+$ & 25 & 11.9 \\
\hline
\end{tabular}

\section{Visitation to Lesvos}

Table 2 presents information regarding visitation to Lesvos Island, information source about Lesvos, and visitation to sacred sites. From the sample (210 participants who visited a sacred place), 97\% (204 participants) had previously visited Lesvos with $40.0 \%$ visited more than 3 times. Regarding the reasons for previous visitation to the island, all 204 participants stated that they were religionrelated. These results revealed that the vast majority of the tourists that come to Lesvos for religious related reasons had visited the Island before $(97 \%)$ and for the same reasons. This finding reveals that these tourists are "loyal" towards this destination. This is in accordance to the World Religious Travel Association (WRTA) which point out that these tourists belong in the category of "repetitive" tourists
(Xenodochos, 2010). This finding also shows that there is a huge market potential, which if the local society acts properly may gain this market share and prosper its economy.

More than $73.0 \%$ of the sample came with a group or their family to Lesvos. As regarding visitation to monasteries and churches more than $90.0 \%$ had visited the Monastery of Saints Raphael, Nicholas and Eirini and visited Taxiarches Monastery - Mantamados. Results also revealed that for first visitation information was gathered via Word of Mouth. Specifically, friends were the main source of information for more than one half of the sample, while more than on third had received information about Lesvos from relatives; tour operators; church and their community. As to marketing related information sources, these are considered quite 
Table 2. Visitation information regarding Lesvos Island, source of information and visitation to monasteries and churches

\begin{tabular}{ll}
\hline Visitation Information & Percentages (\%) \\
\hline Frequency of visitation & 32.3 \\
Once & 33.7 \\
Twice & 16.2 \\
Three times & 14.8 \\
4 or more times & 3.0 \\
Never & \\
& \\
Source of information & 55.0 \\
Friends & 38.0 \\
Relatives & 30.0 \\
Tour Operators & 30.0 \\
Church and Community & 21.0 \\
Internet & 15.0 \\
Special tourism shows on TV & 13.3 \\
Brochures and travel guides & 4.8 \\
GNTO & 5.7 \\
Commercials & 9.0 \\
Magazines & 4.0 \\
Newspapers & \\
Companion & \\
Group & 40.5 \\
With Family & 32.9 \\
With Companion & 16.2 \\
Alone & 10.4 \\
Visitation of specific sacred sites & \\
Monastery of Saints Raphael-Nicholas and Irene & \\
Taxiarches Monastery - Mantamados & 97.0 \\
Church of St Mary the Virgin in Agiasos & 94.0 \\
Panagia of Petra & 78.0 \\
Limonos and St. Ignatius Monastery & 67.0 \\
Other Monasteries & 58.0 \\
\hline Total Sample: & 37.0 \\
\hline & 210 \\
\hline
\end{tabular}

low, along with the information gathered via the GNTO, which is the organization designing and implementing tourism plans. This indicates that reference groups are very highly praised regarding information of religious tourism while marketing related or government resources are not significant. This may be because they do not trust these sources of information, or are not aware that they exist (GNTO, brochures, special vacation magazines, etc). This also indicates that religious tourism will increase when the Bishoprics cooperate at domestic or international level, providing its pilgrims with low cost religious vacations or pilgrimage tourism.

\section{Religious tourism motivation}

Fifteen items were included in the questionnaire in order to measure motivation for visiting a sacred site, i.e. a monastery or church (Table 3). The 15 motivation components produced by previous literature and qualitative depth interviews were then tested on a 5-point Likert attitudinal scale. The scale had as point $5=$ strongly agree, $4=$ agree, $3=$ neither agree $/$ nor disagree, $2=$ disagree, and $1=$ strongly disagree. Specifically tourists were asked to point their degree of agreement towards each component which is "reflecting their motivation for visiting a sacred site monastery or church in Lesvos Island". Means Score of each item is presented on Table 3 . The reliability of the total scale used was Cronbach $\alpha=0.821$, indicating high 
Table 3. Motives regarding visitation to monasteries and churches in Lesvos Island

\begin{tabular}{lllllll}
\hline Statements & $\begin{array}{l}\text { Strongly } \\
\text { Agree }\end{array}$ & Agree & $\begin{array}{l}\text { Neither } \\
\text { agree/nor } \\
\text { disagree }\end{array}$ & Disagree & $\begin{array}{l}\text { Strongly } \\
\text { Disagree }\end{array}$ & MS \\
\hline To worship & 46.6 & 46.3 & 4.7 & 2.4 & 0.0 & 4.53 \\
I have made a vow & 28.8 & 54.4 & 13.0 & 3.8 & 0.0 & 4.08 \\
In order to get well (health reasons) & 38.9 & 39.9 & 8.7 & 9.6 & 2.9 & 4.02 \\
Psychological Balance & 30.3 & 43.8 & 14.9 & 11.0 & 0.0 & 3.93 \\
Act of repentance & 28.8 & 54.4 & 13.0 & 3.8 & 0.0 & 3.92 \\
Inner serenity & 24.0 & 50.0 & 15.9 & 10.1 & 0.0 & 3.88 \\
Inner quest & 22.6 & 50.5 & 15.4 & 11.5 & 0.0 & 3.84 \\
To receive God's help (except health) & 29.8 & 32.2 & 28.4 & 9.6 & 0.0 & 3.82 \\
For the experience & 11.1 & 31.7 & 38.9 & 18.3 & 0.0 & 3.64 \\
Cultural reasons & 16.3 & 30.1 & 32.4 & 16.9 & 4.3 & 3.34 \\
$\begin{array}{l}\text { For events of the monastery or church (eg } \\
\text { fete) } \\
\text { Out of curiosity }\end{array}$ & 17.8 & 26.0 & 24.0 & 19.2 & 13.0 & 3.16 \\
Research /educational reasons & 12.0 & 26.9 & 22.1 & 31.3 & 7.7 & 3.04 \\
To do shopping & 7.7 & 24.0 & 27.4 & 33.6 & 7.3 & 2.94 \\
It is in "fashion"- it is trendy & 5.3 & 11.0 & 19.7 & 42.8 & 21.2 & 2.37 \\
\hline
\end{tabular}

internal consistency of scale (Hair et al., 2010:125).

Results revealed that the three statements with the higher Mean Score were "To worship", "I have made a vow" and "In order to get well (health reasons)", revealing that main reasons for religious tourism are pilgrimage reasons and secondly personal reasons, specifically regarding health. On the other hand, from the results it is obvious that pure secular reasons are not considered as motives to visit a sacred site (monastery or church) in Lesvos Island. This implies that the island is popular for its sacred sites and could increase its potential visitors by organized off-season tourist packages. This also implies that even though Lesvos is an Island, it can "move away" from the "sea and sun" offering, since it seems to have a large potential for an alternative form of tourism.

\section{Factor analysis}

The items rated for tourists' motivation were exploratory factor analysed with Principle Component Analysis and varimax rotation in order to capture the underlying dimensions of tourists' motivation. Factors with eigenvalues greater than one were detained. Item with loading on the factor $<0.50$ or item that loaded on more than one factor was discarded. In this manner, one item had to be eliminated "To do shopping". In the factor analysis, the indicators Kaiser-Meyer-Olkin measure of sampling (KMO), Bartlett Test of Sphericity (BTS) and Significance $(p)$ are presented, which are indicators of competence implementation of the model Principal Component Analysis (Hair et al., 2010). Factor analysis extracted three factors (K.M.O. $=0.711$; B.T.S $=1129.879$; $\mathrm{df}=91$; $\mathrm{p}=0.00$ ) accounting for $66.5 \%$ of the Total 
Table 4. Factors based on motivation for religious tourism

\begin{tabular}{|c|c|}
\hline Factor - Item & Factor loading \\
\hline \multicolumn{2}{|c|}{$\begin{array}{l}1^{\text {st. }} \text { "Secular and cultural motives" } 28.7 \% \text { of the total variance (T.V.); } \alpha=0.756 \text {; Mean Factor Score (MFS) } \\
=2.89(0.82)\end{array}$} \\
\hline Out of curiosity & 0.789 \\
\hline Cultural reasons & 0.767 \\
\hline For events of the monastery or church (e.g. fete) & 0.727 \\
\hline Research / educational reasons & 0.679 \\
\hline It is in "fashion"- it is trendy & 0.595 \\
\hline \multicolumn{2}{|c|}{$2^{\text {nd: }}$ "Pilgrimage motives"; $20.1 \%$ of T.V.; $\alpha=0.745 ;$ MFS $=4.09(0.63)$} \\
\hline To worship & 0.808 \\
\hline I have made a vow & 0.798 \\
\hline Act of repentance & 0.707 \\
\hline In order to get well (Health reasons) & 0.701 \\
\hline To receive Gods help (other than health reasons) & 0.667 \\
\hline \multicolumn{2}{|c|}{$3^{\text {rd: }}$ "Spiritual motives" $17.7 \%$ of T.V.; $\alpha=0.754 ;$ MFS $=3.86(0.80)$} \\
\hline Psychological balance & 0.837 \\
\hline Inner serenity & 0.742 \\
\hline Internal quest & 0.732 \\
\hline For the experience & 0.692 \\
\hline
\end{tabular}

Sample: 208 (K.M.O. $=0.711 ;$ B.T.S $=1029.897 ; \mathrm{df}=91 ; p=0.00$ ). Total variance explained: $66.5 \%$

Variance (T.V.). Table 4 summarizes the results of the factor analysis.

After a closer examination of the loadings, a name was assigned to each factor according to the content of the variables making the greatest contribution to each of the dimensions. Cronbach alpha coefficient was computed to assess the internal consistency among the set of items on each factor. Results revealed that Cronbach alpha in all cases was a> 0.700, price acceptable according to Nunnally (1978).

In this matter F1 (Factor 1) was named "Secular and cultural motives" because it has to do with secular and cultural motives for sacred site visitation. This factor contains five items and has mean score $2.89(\mathrm{StD}=0.82)$. This implies that participants tend to neither agree nor disagree towards this factor and the items it contains as being motives for materializing a religious trip to Lesvos Island. This factor has 3 out of 5 items with relatively high loadings (0.727-0.789); with highest factor loading on the item: "Out of curiosity" (0.789), and lowest on the item: "It is in "fashion"- it is trendy" (0.595). Within each identified motive factor regarding visiting monasteries and churches in Lesvos Island, the item's loading on the factor shows the importance of the motive element. According to table 4, while the first factor "Secular and cultural motives" explains $28.7 \%$ of the TV, it has the smallest MFS, compared to the other factors (MFS=2.89). Hence in this manner it cannot be considered as the most important factor. From this factor, the items that have the highest loadings, and for so are identifying tourists deeper motives regarding their "Secular and cultural motives", is "out of curiosity", which has the highest factor loading (0.789) on the factor, and $38.9 \%$ of the sample agree or completely agree that curiosity was a motive for their religious tourism. Also, the item "Cultural reasons" has a relatively high factor loading (0.767). Towards this item $46.4 \%$ of the participants agree or completely agree as being a motive for religious tourism. "For the events of the monastery or church (e.g. fete)" which is 
the third item with relatively high loading on the factor, there is a $43.8 \%$ that do consider churches' or monasteries' events as motivators for their visitation to the religious setting. For the "Research / educational reasons" and "It is in "fashion"- it is trendy", only $31.7 \%$ and $17.7 \%$ respectively agree or completely agree that are motives for visiting a sacred setting (monastery or church) in Lesvos Island.

F2 (Factor 2) was named "Pilgrimage motives" because this factor has to do with pilgrimage motives for sacred site visitation. It consists of five items and has mean score 4.09 $(S t D=0.63)$. This implies that participants agree towards this factor and the items it contains as being motives for materializing a religious visitation to Lesvos Island. This factor explains $20.1 \%$ of the TV, and has the highest MFS, compared to the other factors. Hence in this manner it can be considered as the most important factor. Moreover, this factor has 4 out of 5 items with relatively high loadings (0.7010.808). Thus, regarding this factor and depending on the factor loading, the main reason for visiting the monasteries and churches was "To worship" (0.808) and least the item "To receive Gods help (other than health reasons)" (0.667).

As to the high loading items on the factor, the percentages of the sample that agree or strongly agree with the motivation reasons to visit a monastery or church in Lesvos island are as follows: "To worship" (92.9\%); "I have made a vow" (83.2\%); "Act of repentance" (83.2\%); "In order to get well (Health reasons)" $78.8 \%$, and "To receive Gods help (other than health reasons)" for the $62.0 \%$ of the sample. Regarding this factor, religion and religiosity is a very sensitive matter and personal factor. Thus, marketing officials must be very careful regarding the way and means that they will promote the island as a religious tourist destination. With the use of technology, and specifically internet, they may to create "tourist awareness" sites recording the miracles of the different monasteries and churches. In this way, they can trigger potential tourists to visit the island.

F3 (Factor 3) was named "Spiritual motives" because this factor has to do with spiritual motives for sacred site visitation. This factor explains $17.7 \%$ of the T.V., and has the second highest MFS, compared to the other factors. Hence in this manner it can be considered as the second most important factor. It consists of four items and has MFS=3.89 $(\mathrm{StD}=0.80)$. This implies that participants tend to agree towards this factor and the items it contains as being motives for visiting Lesvos Island. This factor also has relatively high factor loadings for three out of four items (0.732- 0.837); has the highest factor loading on the item: "Psychological balance" (0.837), and lowest on the item: "For the experience" (0.692).

The factor has MFS=3.86 (StD=0.80), indicating that tourists tend to agree that this factor is a motive for undertaking the religious trip to Lesvos Island. Regarding the high loading items on the factor: Psychological balance, inner serenity, and internal quest; $74.1 \% ; 74.0 \%$; and $73.1 \%$ of the sample agree or strongly agree that these statements constitute motivational reasons for visiting a sacred setting in Lesvos. Lastly, for the fourth item "for the experience", $42.8 \%$ of the sample considered it also as a motive for going to monasteries and churches in Lesvos.

Regarding this factor, an advertising campaign from the local authorities could be implemented. This would focus on the tranquillity and serenity that the island has to offer combined with the scenery and its monasteries and churches. This campaign could lead to desired tourist related outcomes, all year round and not only on religious holidays.

Concerning the three factors the results indicate that Lesvos Island may profit regarding not only the religious tourism share but the secular tourism market also. This may be accomplished by pointing out in a campaign, the information regarding Greek and Lesvos Island's history and cultural sites.

Lastly, the above factors are partially consistent with previous studies. Chand (2010) studying 500 domestic visitors and 500 non-resident Indians visiting Sacred Sites in India found five motivational factors: Cultural Immersion, Religious Attraction, Seeking Camaraderie, 
Novelty, and Family Togetherness. Wong et al. (2013) who found three motivational factors for visiting monasteries of Putuoshan, China: general sightseeing, degree of belief in Buddhism, to ask and give thanks. Shuo et al. (2009) regarding Mazu tourism in Taiwan found three motivational factors: social exploration, experiencing religion, and experiencing belief.

\section{Conclusions}

This research deals with the components of religious tourism motivation, a topic very little researched; and thus covers this gap. This research aimed to investigate tourists' motivations for visiting sacred sites in Lesvos Island, i.e. the monasteries and churches. This was realized through qualitative as well as quantitative research. From the qualitative research, 15 motivational items were identified, which were in the same direction with literature review, and were continuously tested in the field study. Also, it had as objectives to record previous visitation and purpose of previous visitation to Lesvos Island. This was accomplished through quantitative research which revealed that the $97 \%$ of the sample had already visited in the past at least once the Island, mainly for religious reasons. Its second objective was to examine the source of information for visitation, and if participants visited the monasteries and churches in Lesvos. Findings suggest that WOM was the main informative source. The 210 participants who stated that they had visited a monastery or church were considered as the subjects of the research. Main motives for visiting the monasteries and churches were "To worship", "I have made a vow" and "In order to get well (health reasons)". Lastly, the third objective of this study was to extract the underlying factors of tourists' motivations for visiting monasteries and churches in Lesvos. This objective was accomplished through factor analysis and with the method of principle component analysis with varimax rotation. Factor analysis extracted three factors accounting for $66.5 \%$ of the total variance. These factors namely were "Spiritual motives", "Pilgrimage motives" and "Secular and cultural motives". Thus, the results revealed that for the Greeks, motives for visiting religious sites in Lesvos Island are secular, pilgrimage and spiritual. These findings come to partial accordance with the findings of other researchers (i.e. Terzidou, 2010; Tirca et al., 2010; Vidic, 2007). For example, Terzidou (2010) found that motives for visiting sacred places in Tinos island were "had a vow", "seek therapy", "relieve them from pain", and other secular motives. The differences could be explained due to the fact that there are different forms of religious tourism based on pragmatic variables such as social status (Rinschede, 1992) and the different appeal and attractiveness that religious sites have for different visitors (Nolan and Nolan, 1992).

This study is one of the few that explored tourists' motivations for visiting religious sites in Greece. Despite the interesting findings of this study and an attempt to minimize limitations when designing this research, still some exist and need to be mentioned. First of all, the outcomes of this study may not have represented all religious tourists, Greeks or international tourists that visit a Greek religious setting. This research was limited only to the island of Lesvos and the religious settings that exist there (e.g. monasteries, churches, and the icons and remains of the saints). Since each religious site in Greece is unique, further research to other religious places is necessary in order to validate the findings. Moreover, this study used 15 items to measure visitors' motivations to visit Lesvos religious settings; the ones that were repeatedly mentioned in the qualitative research. Further research should be undertaken in order to explore if other items should be included in measuring motivations for religious tourism. Future studies should also include local residents' opinions' towards this particular form of tourism provided by their area of residence.

\section{References}

Andriotis, K. (2009). Sacred Site Experience. A Phenomenological Study. Annals of Tourism Research, 36(1), 64-84.

Aslan, D. and Andriotis, K. (2009). Clustering Visitors to a religious island - The case of Tinos. Paper presented at the International Conference on Tourism Development and Management (ICTDM): Tourism in a Changing World: Prospects and Challenges, September 11-15, Kos Island, 
Greece.URL:

https://www.academia.edu/899772/Asl

an_D._and_Andriotis_K.

2009_._Clustering_Visitors_to_a_Religi

ous_Island_The_Case_of_Tinos.

Paper_presented_at_the_International _Conference_on_Tourism_Developme

nt_and_Management_ICTDM_Tourism in_a_Changing_World_Prospects_an

d_Challenges_September_11-

15_2009_Kos_Island_Greece

(Accessed on 10 October, 2013)

Burr, S.W., Parajuli, K. \& Reiter, D.K. (2007).

An assessment of the Utah tourism industry's perceptions of hospitality and customer service training. IORT Professional Report, PR2007-02, Institute for Outdoor Recreation and Tourism Utah State University. URL: http://extension.usu.edu/iort/files/uploa ds/pdfs/hospitalityesurveyreport9-1307.pdf (Accessed on 07 October, 2013)

Chand, M. (2010). A cross-national study of motivational determinants among nonresident Indian visitors to religious centers in India. International Journal of Hospitality \& Tourism Administration, 11 (1), 22-38

Collins-Kreiner, N., \& Kliot, N. (2000). Pilgrimage tourism in the Holy Land: The behavioral characteristics of Christian pilgrims. Geo Journal, 50(1), 55-67.

della Dora, V. (2012). Setting and blurring boundaries: Pilgrims, tourists, and landscape in Mount Athos and Meteora. Annals of Tourism Research, 39 (2), 951-974

Drule, A.M., Chiş, A., Băcilă, M. F. \& Ciornea, R. (2012). A new perspective of nonreligious motivations of visitors to sacred sites: evidence from Romania. Procedia - Social and Behavioral Sciences, 62, 431-435.

Egresi, I., Bayram, B. \& Kara, F. (2012). Tourism at religious sites: A Case from Mardin, Turkey. Geographica Timisiensis, 21(1), 5-15

Ethnos (2010). Mytilene: History and nobility of centuries. (In Greek). URL: http://www.ethnos.gr/entheta.asp?catid $=23522$ \& subid $=2 \&$ pubid $=1042573$. (Accessed on 7 September 2010)
Hair, J., Anderson, R., Tatham, R., \& Black, W. (2010). Multivariate data analysis (7th ed.). Upper Saddle River, NJ: PrenticeHall

Hughes, K., Bond, N., Ballantyne, R. (2013). Designing and managing interpretive experiences at religious sites: Visitors' perceptions of Canterbury Cathedral. Tourism Management, 36, 210- 220.

Hyde, K.F., and Harman S., (2011). Motives for a secular pilgrimage to the Gallipoli battlefields. Tourism Management, 32, 1343-1351

Kamenidou, I. (1999). Market Research of Processed Peach products in the Urban Design Unit of Thessaloniki, Greece. PhD thesis, Aristotle University of Thessaloniki, School of Agricultural Sciences, Dept. of Agriculture, Division of Agricultural Economics, Special Division: Marketing of Agricultural Products. (in Greek).

Kamenidou I., Mamalis, S., \& Priporas, C.V. (2009). Measuring destination image and consumer choice criteria. The case of Mykonos Island. TOURISMOS: An International Multidisciplinary Journal of Tourism, 4(3), 67-79

Kotsi, F. (2012). Mount Athos: development policies for short-term religious tourism. International Journal of Tourism Anthropology, 2(2), 149-163.

Nieminen, K. (2009). Religious tourism - a Finnish perspective. Master Thesis in Hospitality Management, HAAGAHELIA, University of Applied Sciences, Helsinki, Finland. URL: http://theseus17-k.lib.helsinki.fi /bitstream/handle/10024/51755/Niemin en_Katri.pdf?sequence $=1 \quad$ (Accessed on 07 October, 2013)

Nolan, M. L., \& Nolan, S. (1992). Religious sites as tourism attractions in Europe. Annals of Tourism Research, 19(1), 6878.

Nunnally, J. C. (1978). Psychometric theory (2nd ed.). New York: McGraw-Hill.

Petreas, C. (2011). The conflicting interactions among stakeholders in religious and pilgrimage sites. Proceedings of the international conference on tourism (ICOT 2011). Tourism in an Era of Uncertainty. Rhodes Island, Greece 
27-30 April, pp. 550-563. Eds: Andriotis, K., Theocharous, A., Kotsi, F., International Association for Tourism Policy.

Poria, Y., Butler, R., \& Airey, D. (2003). Tourism, religion and religiosity: A Holy mess. Current Issues in Tourism, 6(4), 340-363.

Priporas, C.V., Vassiliadis, C. \& Stylos, N. (2012). Qualitative findings on marketing management practices from Greek ski centers. Qualitative Market Research: An International Journal, 15(4), 385-403.

Real Society: The GNTO promotes religious tourism. (2012). URL: http://www.real.gr/DefaultArthro.aspx?p age $=$ arthro\&id $=122112 \&$ cat $I D=3$ (Accessed on 05 February 2012)

Rinschede, G. (1992). Forms of religious tourism. Annals of Tourism Research, 19(1), 51-67.

Rodrigues, S.A.M. (2012). Motivations, experiences and potential impacts of visitors to a monastery in New Zealand: A Case Study. Master thesis, Department of Tourism and Hospitality Management, University of Waikato, New Zealand

Sharpley, R., \& Sundaram, P. (2005). Tourism: a Sacred Journey? The case of Ashram tourism, India. International Journal of Tourism Research, 7, 161171.

Shuo, Y.(S.) S., Ryan, C. \& Liu, G.(M). (2009). Taoism, temples and tourists: The case of Mazu pilgrimage tourism. Tourism Management, 30, 581-588.

Smith, V.L. (1992). Introduction: the quest in guest. Annals of Tourism Research, 19, 1-17.

Spector, P.E. (1992). Summated Rating Scale Construction: An Introduction, Sage University. Paper Series on Quantitative Applications in the Social Sciences, no. 82, Beverly Hills, CA: Sage Publications.

Tarlow, P.E. (2011). Develop your own pilgrimage tourism. URL:http://www.tourismreview.com/travel-tourism-magazinepilgrimage-tourism-is-often-big- business-category1484. (Accessed on 01 October 2013)

Terzidou, M. (2010). Religion as a motivation to travel: The case of Tinos Island in Greece. MIBES, 338 - 349. URL: http://mibes.teilar.gr/proceedings/2010/ oral/59_final.pdf (Accessed on 13 October 2013)

Terzidou, M., Stylidis \& Szivas, E. D. (2008). Residents' perceptions of religious tourism and its socio-economic impacts on the Island of Tinos. Tourism and Hospitality Planning \& Development, 5(2), 113-129.

Timothy, D.J, and Olsen, D.H. (2006). Tourism, religion \& spiritual journeys. New York: Routledge.

Tîrca, A.-M., Stanciulescu, G.C., Chis, A. \& Bacila, M.F. (2010). Managing the visitor experience on Romanian religious sites: Monasteries Abbots' perceptions. URL: http://ideas.repec. org/a/aio/manmar/vviiiy2010is1ps5-

s16.html\#cites. (Accessed on 10 October 2013)

Tomasi, L. (2002). Homo Viator: From pilgrimage to religious tourism via the journey. In W. H. Swatos, Jr., \& L. Tomasi (Eds.): From medieval pilgrimage to religious tourism: The social and cultural economics of piety (pp.1-24). Westport, Conn: Praeger

Triantafillidou, A., Koritos, C., Chatzipanagiotou, K., and Vassilikopoulou A. (2010). Pilgrimages: the "promised land" for travel agents? International Journal of Contemporary Hospitality Management, 22(3), 382-398.

Vidic, N. (2007). Religious tourism as postmodern tourism on the territory of Fruska Gora. University of Craiova; Series: Geography (Universitatea Din Craiova Seria: Geografie) 10, 187-205.

Wong, C.U.I., Ryan,C., \& Mclntosh, A.(2013). The Monasteries of Putuoshan, China: Sites of Secular or Religious Tourism? Journal of Travel \& Tourism Marketing, 30(6), 577-594.

World Tourism Organization (UNWTO). (2011). Religious Tourism in Asia and the Pacific. World Tourism Organization, 
Kamenidou, I. and Vourou, R. (2015) / European Journal of Tourism Research 9, pp. 78-91

Madrid, Spain. URL:

http://dtxtq4w60xqpw.cloudfront.net/ sites/all/files/pdf/110325_religious_touri sm_excerpt.pdf. (Accessed on 10 October 2013)

Xenodochos (2010) Constant value religious http://www.cyprushotelassociation.org/ Xenodochos/xenodoxos23.pdf tourism, with a turnover approaching (Accessed on 07 October, 2013) VisitLesvos(n.d.) URL: http://lesvosgreece.gr/. 15 billion $€$ per year. Xenodoxos, 23, 14-18. URL: 